\title{
Sensitivity of durum wheat (Triticum turgidum) to various postemergence herbicides
}

\author{
Nader Soltani", Christy Shropshire, Peter H. Sikkema \\ University of Guelph Ridgetown Campus, Main Street East, Ridgetown, Ontario, Canada; \\ *Corresponding Author: nsoltani@ridgetownc.uoguelph.ca
}

Received 2 September 2011; revised 15 October 2011; accepted 25 October 2011.

\begin{abstract}
There are a limited number of herbicide options available for durum wheat production in Ontario, Canada. Four field studies were conducted in Ontario, Canada over a three year period (2008, 2009 and 2010) to evaluate the sensitivity of spring planted durum wheat to post-emergence (POST) applications of dichlorprop/2,4-D, dicambal MCPA/mecoprop, clopyralid, bromoxynil/MCPA, pyrasulfotole/bromoxynil, thifensulfuron/tribenuron + MCPA amine, fluroxypyr + MCPA ester, tralkoxydim and fenoxaprop-p-ethyl/safener at the manufacturers' recommended dose and twice that dose. Visible injury in durum wheat were 0 to $2.4 \%$ with dichlorprop/2,4-D, 0 to $6 \%$ with dicamba/MCPA/mecoprop, 0 to $0.4 \%$ injury with clopyralid, 0 to $1.4 \%$ injury with bromoxynil/MCPA, 0 to $3.5 \%$ with pyrasulfotole/bromoxynil, 0 to $5 \%$ with thifensulfuron/tribenuron + MCPA amine, 0 to $2.6 \%$ with fluroxypyr + MCPA ester, 0 to $5 \%$ with tralkoxydim and $0.4 \%$ to $8 \%$ with fenoxaprop-pethyl/safener at various evaluation dates $(1,2,3$ and 4 weeks after treatment). Durum wheat height was decreased as much as $5 \%$ with dicambal MCPA/mecoprop, $4 \%$ with pyrasulfotole/bromoxynil and $6 \%$ with fenoxaprop-pethyl/safener but was not affected with other herbicides evaluated. There was no decrease in durum wheat yield with the herbicides evaluated.
\end{abstract}

Keywords: Durum Wheat; Height; Herbicide Sensitivity; Injury; Tolerance; Yield

\section{INTRODUCTION}

Durum wheat [Triticum turgidum subsp. durum (Desf.) Husn.] is the second most important Triticum species, next to common wheat (Triticum aestivum L.) [1]. Durum wheat has yellow endosperm, high protein content and gluten characteristics which make it popular with processors for pasta products [1]. Globally, 30 million MT of durum wheat are produced on approximately 18 million hectares of land [2]. Most of the durum wheat produced in the world (nearly 8 million MT) is grown in European Union (mainly Italy, Spain and Greece) [2]. Canada is the second largest producer of durum wheat in the world producing nearly 4.6 million MT per year followed by Turkey and the USA which produce 4 and 3.5 million MT, respectively [2]. Most of the durum wheat in Canada is produced in the provinces of Saskatchewan, Alberta and Manitoba [1]. Currently, there is limited production of durum wheat in Ontario. Most of the commercially grown wheat in Ontario belongs to the species Triticum aestivum. As a result of the availability of improved cultivars, local demand and higher returns, there has been renewed interest in durum wheat production in Ontario. There are a limited number of grass and broadleaved herbicides registered for use in durum wheat in Ontario. Durum wheat has been shown to respond differently than conventional wheat to some herbicides [3,4]. Cultivar differences in the tolerance to some herbicides have been reported within $T$. aestivum [5-9]. More research is needed to identify herbicide options for durum wheat in Ontario.

Dichlorprop plus 2,4-D ester (premix formulated), clopyralid and dicamba/MCPA/mecoprop are phenoxy herbicides that are very effective for the control of a wide spectrum of annual, biennial and perennial broadleaf weeds including Polygonum lapathifolium (smartweed), Polygonum convovulus (wild buckwheat), Capsella bursa-pastoris (shepherd's purse), Thlaspi arvense (stinkweed), Lactuca scariola (prickly lettuce) and Tara xacum officinale (dandelion) [10,11]. These are growth regulating herbicides affecting respiration, translocation and cell division [5].

Bromoxynil plus MCPA (premix formulated) is a benzonitrile plus phenoxy herbicide that inhibits photosynthesis and causes uncontrolled cell division and growth in sensitive weeds [11]. Bromoxynil plus MCPA can 
provide control of annual broadleaved weeds such as Xanthium strumarium (cocklebur), Polygonum persicaria (ladysthumb), Chenopodium album (common lambsquarters), Sinapis arvensis (wild mustard), Solanum Spp. (nightshades), Amaranthus retroflexus (redroot pigweed), Ambrosia artemisiifolia (common ragweed), Capsella bursa-pastoris, Thlaspi arvense, Abutilon theophrasti (velvetleaf) and suppression of perennial broadleaf weeds such as Convolvulus arvensis (field bindweed), Sonchus arvensis (perennial sow-thistle) and Cirsium arvense (Canada thistle) [10].

Thifensulfuron-methyl plus tribenuron-methyl (premix formulated) are sulfonylurea herbicides that inhibit the activity of accetolactate synthase (ALS), an important enzyme necessary for the biosynthesis of branched chain amino acids, isoleucine, leucine and valine [11]. Thifensulfuron-methyl plus tribenuron-methyl is applied at a low dose, has low mammalian toxicity and controls several broadleaved weeds including triazine-resistant biotypes that occur in Ontario such as Polygonum convovulus, Spergula arvensis (corn spurry), Galeopsis tetrahit (hempnettle), Polygonum persicaria, Chenopodium album, Sinapis arvensis, Amaranthus retroflexus, Capsella bursa-pastoris, and Thlaspi arvense, [10].

Tralkoxydim and fenoxaprop-p-ethyl are post-emergence (POST) herbicides that inhibit acetyl-CoA carboxylase (ACCase), the enzyme needed for fatty acid synthesis and subsequent production of phospholipids needed for cell membranes in plants. These herbicides are very effective for the control of a wide spectrum of annual grass species including Setaria viridis (green foxtail), Setaria glauca (yellow foxtail), Echinochloa crusgalli (barnyardgrass) and Avena fatua (wild oats) [10, 11].

There is limited information published on the sensitivity of durum wheat to dichlorprop/2,4-D, dicamba/MCPA/ mecoprop, clopyralid, bromoxynil/MCPA, pyrasulfotole/ bromoxynil, thifensulfuron/tribenuron + MCPA amine, fluroxypyr + MCPA ester, tralkoxydim and fenoxapropp-ethyl/safener under Ontario environmental conditions. Currently, dichlorprop/2,4-D, clopyralid, pyrasulfotole/ bromoxynil, fluroxypyr plus MCPA ester, fenoxapropp-ethyl/safener are not registered for use in durum wheat in eastern Canada. If tolerance is adequate, the availability of these herbicides would provide growers with additional herbicide mode-of-actions for the control of broadleaved and grass weeds in spring planted durum wheat.

The objective of this research was to evaluate tolerance of durum wheat to POST applications of dichlorprop/2,4-D, dicamba/MCPA/mecoprop, clopyralid, bromoxynil/MCPA, pyrasulfotole/bromoxynil, thifensulfuron/tribenuron + MCPA amine, fluroxypyr + MCPA ester, tralkoxydim and fenoxaprop-p-ethyl/safener at the manu- facturers' recommended dose and sequentially at that dose to simulate a spray overlap in the field.

\section{MATERIALS AND METHODS}

Four field studies were conducted at the Huron Research Station, Exeter, Ontario over a three-year period (2008, 2009, 2010a, 2010b). The soils for the study sites were a Brookston clay loam with $44 \%$ sand, $33 \%$ silt, $23 \%$ clay, $4.1 \% \mathrm{OM}$ and $\mathrm{pH}$ of 7.9 in $2008,34 \%$ sand, $36 \%$ silt, $30 \%$ clay, $3.6 \% \mathrm{OM}$ and $\mathrm{pH}$ of 8.0 in 2009 , and $35 \%$ sand, $43 \%$ silt, $22 \%$ clay, $4 \% \mathrm{OM}$, and $\mathrm{pH}$ of 7.8 in 2010. Seedbed preparation consisted of moldboard plowing in the autumn followed by two passes with a cultivator with rolling basket harrows in the spring.

Experiments were arranged in a randomized complete block design with four replications. There were 21 treatments as listed in Table 1. Plots were $2 \mathrm{~m}$ wide by $10 \mathrm{~m}$ long. Durum wheat "Hallmark" was seeded with a double disc drill at $150 \mathrm{~kg} \cdot \mathrm{ha}^{-1}$ in rows spaced $17.5 \mathrm{~cm}$ apart at a depth of $4 \mathrm{~cm}$ on April 18, 2008, April 15, 2009 and April 3 and 5, 2010 at site a and b, respectively.

Herbicides were applied POST at Zadoks stage 22 to 32. Treatments were applied with a $\mathrm{CO}_{2}$ pressurized backpack sprayer calibrated to deliver $200 \mathrm{~L} \cdot \mathrm{ha}^{-1}$ aqueous solution at $241 \mathrm{kPa}$. The boom was $1.5 \mathrm{~m}$ long with four Hypro ULD120-02 nozzle tips (Hypro, New Brighton, MN, USA) spaced $50 \mathrm{~cm}$ apart. All plots including the untreated control were kept weed-free as needed.

Visible crop injury was rated on a scale of 0 to $100 \%$ $(0=$ no visible injury and $100=$ plant death $)$ at approximately 1, 2, 3, 4 and 8 weeks after POST treatment (WAT). Ten plants were randomly selected per plot and the height from the soil surface to the highest growing point of each plant was measured at 8 WAT. Durum wheat was harvested at maturity (late July to early August) using a plot combine and yields were adjusted to $14.5 \%$ moisture.

All data were subjected to analysis of variance. Tests were combined over environments and analyzed using the MIXED procedure of SAS [12]. Variances were partitioned into the random effects of location, years, location by years, blocks within years by location and the interactions with fixed effects (herbicide treatments). Significance of random effects were tested using a Z-test of the variance estimate and fixed effects were tested using F-tests. Error assumptions of the variance analyses (random, homogeneous, normal distribution of error) were confirmed using residual plots and the ShapiroWilk normality test. To meet assumptions of normality, injury data were square-root or arcsine square-root trans- 
formed as needed. Means were converted back to the original scale for presentation of results. Untreated check was not included in analysis of injury. However, all values were compared independently to zero to evaluate treatment differences with the untreated check. Means were separated using Fisher's protected LSD at $\mathrm{P}<0.05$.

\section{RESULTS AND DISUSSION}

Environment by treatment interaction was significant for all injury ratings. Height and yield could be combined across environments. Visible injury was zero for all treatments evaluated at 8 WAT and were not analyzed.

\subsection{Injury}

Injury symptoms included chlorosis, necrosis (leaf tip burn), growth distortion and plant height reduction. Visible injury in durum wheat was 0 to $2.4 \%$ with dichlorprop/2,4-D, 0 to $6 \%$ with dicamba/MCPA/mecoprop, 0 to $0.4 \%$ injury with clopyralid, 0 to $1.4 \%$ injury with bromoxynil/MCPA, 0 to $3.5 \%$ with pyrasulfotole/bromoxynil, 0 to $5 \%$ with thifensulfuron/ tribenuron + MCPA amine, 0 to $2.6 \%$ with fluroxypyr + MCPA ester, 0 to $5 \%$ with tralkoxydim and $0.4 \%$ to $8 \%$ with fenoxaprop-p-ethyl/safener at the various evaluation dates (Tables 1 and 2). Generally, injury was greater at the higher dose for the herbicides evaluated although results were not always statistically significant. Injury

Table 1. Durum wheat injury 1 and 2 WAT for various postemergence treatments. Means followed by the same letter within a column are not significantly different according to Fisher's Protected LSD at $\mathrm{P}<0.05^{\mathrm{a}}$.

\begin{tabular}{|c|c|c|c|c|c|c|}
\hline \multirow{3}{*}{ Treatments } & \multirow{3}{*}{$\begin{array}{c}\text { Dose } \\
\mathrm{g} \cdot \mathrm{ai}^{-} \mathrm{ha}^{-1}\end{array}$} & \multicolumn{3}{|c|}{ Injury 1 WAT } & \multicolumn{2}{|c|}{ Injury 2 WAT } \\
\hline & & 2008 & 2009 & 2010 & 2009 & 2010 \\
\hline & & \multicolumn{5}{|c|}{$\%$} \\
\hline Untreated control & & $0 \mathrm{a}$ & $0 \mathrm{a}$ & $0 \mathrm{a}$ & $0 \mathrm{a}$ & $0 \mathrm{a}$ \\
\hline Dichlorprop/2,4-D & 1017 & 0 a & $2.0 \mathrm{~cd}$ & $0.9 \mathrm{a}$ & $0 \mathrm{a}$ & $0 \mathrm{a}$ \\
\hline Dichlorprop/2,4-D & $1017 ; 1017$ & $0 \mathrm{a}$ & $2.4 \mathrm{~cd}$ & $0.2 \mathrm{a}$ & $1.4 \mathrm{bcd}$ & $0 \mathrm{a}$ \\
\hline Dicamba/MCPA/mecoprop & 600 & $0 \mathrm{a}$ & $1.3 \mathrm{bc}$ & $0 \mathrm{a}$ & $0.8 \mathrm{abc}$ & $0 \mathrm{a}$ \\
\hline Dicamba/MCPA/mecoprop & $600 ; 600$ & $0.4 \mathrm{a}$ & 3.4 de & $0 \mathrm{a}$ & $1.9 \mathrm{~cd}$ & $0.2 \mathrm{~b}$ \\
\hline Clopyralid & 200 & $0 \mathrm{a}$ & $0 \mathrm{a}$ & 0 a & $0 \mathrm{a}$ & $0 \mathrm{a}$ \\
\hline Clopyralid & $200 ; 200$ & $0 \mathrm{a}$ & $0.4 \mathrm{ab}$ & $0 \mathrm{a}$ & $0 \mathrm{a}$ & $0 \mathrm{a}$ \\
\hline Bromoxynil/MCPA & 560 & $0 \mathrm{a}$ & $0 \mathrm{a}$ & $0 \mathrm{a}$ & $0 \mathrm{a}$ & $0 \mathrm{a}$ \\
\hline Bromoxynil/MCPA & $560 ; 560$ & $0 \mathrm{a}$ & $1.4 \mathrm{bc}$ & $0 \mathrm{a}$ & $0 \mathrm{a}$ & $0 \mathrm{a}$ \\
\hline Pyrasulfotole/bromoxynil ${ }^{\mathrm{b}}$ & 213 & $0 \mathrm{a}$ & $0 \mathrm{a}$ & $0 \mathrm{a}$ & $0 \mathrm{a}$ & $0 \mathrm{a}$ \\
\hline Pyrasulfotole/bromoxynil ${ }^{\mathrm{c}}$ & $213 ; 213$ & $0 \mathrm{a}$ & $0 \mathrm{a}$ & $0 \mathrm{a}$ & $0 \mathrm{a}$ & $0 \mathrm{a}$ \\
\hline Thifensulfuron/tribenuron + MCPA amine ${ }^{\mathrm{d}}$ & $15+550$ & $0 \mathrm{a}$ & 3.4 de & $0 \mathrm{a}$ & $2.0 \mathrm{~cd}$ & $0 \mathrm{a}$ \\
\hline Thifensulfuron/tribenuron + MCPA amine ${ }^{e}$ & $\begin{array}{l}15+550 \\
15+550\end{array}$ & $0 \mathrm{a}$ & $5.0 \mathrm{e}$ & $0.2 \mathrm{a}$ & 3.9 e & $0 \mathrm{a}$ \\
\hline Fluroxypyr + MCPA ester & $108+562$ & $0 \mathrm{a}$ & $1.4 \mathrm{bc}$ & $0 \mathrm{a}$ & $0 \mathrm{a}$ & $0 \mathrm{a}$ \\
\hline Fluroxypyr + MCPA ester & $\begin{array}{c}108+562 \\
108+562\end{array}$ & $0 \mathrm{a}$ & $2.6 \mathrm{~cd}$ & $0 \mathrm{a}$ & $0 \mathrm{a}$ & $0 \mathrm{a}$ \\
\hline Tralkoxydim $^{\mathrm{f}}$ & 200 & $0 \mathrm{a}$ & $2.6 \mathrm{~cd}$ & $0.9 \mathrm{a}$ & $1.4 \mathrm{bcd}$ & $0.6 \mathrm{~b}$ \\
\hline Tralkoxydim ${ }^{\mathrm{g}}$ & $200 ; 200$ & $1.4 \mathrm{~b}$ & $5.0 \mathrm{e}$ & $2.6 \mathrm{~b}$ & 2.4 de & $2.1 \mathrm{c}$ \\
\hline Fenoxaprop-p-ethyl/safener & 92.4 & $4.1 \mathrm{c}$ & 3.4 de & $4.9 \mathrm{c}$ & $0.4 \mathrm{ab}$ & $3.0 \mathrm{c}$ \\
\hline Fenoxaprop-p-ethyl/safener & $92.4 ; 92.4$ & $8.0 \mathrm{~d}$ & $5.5 \mathrm{e}$ & $1.9 \mathrm{~d}$ & $0.8 \mathrm{abc}$ & $5.2 \mathrm{~d}$ \\
\hline SE & & 0.2 & 0.2 & 0.2 & 0.2 & 0.1 \\
\hline
\end{tabular}

${ }^{a}$ Abbreviations: WAT, weeks after treatment. ${ }^{\mathrm{b}}$ Included ammonium sulfate $\left(1.0 \mathrm{~L}^{\mathrm{h}} \mathrm{ha}^{-1}\right)$. ${ }^{\mathrm{c}}$ Included ammonium sulfate $\left(1.0 \mathrm{~L} \cdot \mathrm{ha}^{-1} ; 1.0 \mathrm{~L} \cdot \mathrm{ha}{ }^{-1}\right) .{ }^{\mathrm{d}}$ Included non-ionic surfactant $(0.2 \% \mathrm{v} / \mathrm{v})$. ${ }^{e}$ Included non-ionic surfactant $(0.2 \% \mathrm{v} / \mathrm{v} ; 0.2 \% \mathrm{v} / \mathrm{v})$. ${ }^{\mathrm{f}}$ Included mineral oil $/$ surfactant $(0.5 \% \mathrm{v} / \mathrm{v})$. ${ }^{8}$ Included mineral oil/surfac$\operatorname{tant}(0.5 \% \mathrm{v} / \mathrm{v} ; 0.5 \% \mathrm{v} / \mathrm{v})$. 
Table 2. Durum wheat injury 3 and 4 weekd after treatment (WAT), height and yield for various postemergence treatments. Means followed by the same letter within a column are not significantly different according to Fisher's Protected LSD at P $<0.05$.

\begin{tabular}{|c|c|c|c|c|c|c|c|}
\hline \multirow{3}{*}{ Treatments } & \multirow{3}{*}{$\begin{array}{c}\text { Dose } \\
\mathrm{g} \cdot \mathrm{ai}^{-} \mathrm{ha}^{-1}\end{array}$} & \multicolumn{2}{|c|}{ Injury 3 WAT } & \multicolumn{2}{|c|}{ Injury 4 WAT } & \multirow{3}{*}{$\begin{array}{l}\text { Height }^{\mathrm{a}} \\
\text { cm }\end{array}$} & \multirow{3}{*}{$\begin{array}{l}\text { Yield } \\
\mathrm{t} \mathrm{ha}^{-1}\end{array}$} \\
\hline & & $\begin{array}{c}2008 \& \& \\
2009\end{array}$ & 2010 & $\begin{array}{c}2008 \& \\
2009\end{array}$ & 2010 & & \\
\hline & & \multicolumn{4}{|c|}{$\%$} & & \\
\hline Untreated control & & $0 \mathrm{a}$ & $0 \mathrm{a}$ & $0 \mathrm{a}$ & $0 \mathrm{a}$ & $71.2 \mathrm{abc}$ & 4.11 \\
\hline Dichlorprop/2,4-D & 1017 & $0 \mathrm{a}$ & $0 \mathrm{a}$ & $0.5 \mathrm{abc}$ & $0 \mathrm{a}$ & $71.2 \mathrm{abc}$ & 4.29 \\
\hline Dichlorprop/2,4-D & $1017 ; 1017$ & $1.0 \mathrm{ab}$ & $0 \mathrm{a}$ & 1.5 bcde & $0 \mathrm{a}$ & $72.3 \mathrm{a}$ & 4.30 \\
\hline Dicamba/MCPA/mecoprop & 600 & $1.1 \mathrm{ab}$ & $3.7 \mathrm{c}$ & $1.0 \mathrm{abcd}$ & $2.8 \mathrm{~b}$ & 68.8 de & 4.11 \\
\hline Dicamba/MCPA/mecoprop & $600 ; 600$ & $4.1 \mathrm{~d}$ & $6.0 \mathrm{c}$ & 3.6 ef & $5.1 \mathrm{c}$ & $67.4 \mathrm{ef}$ & 4.13 \\
\hline Clopyralid & 200 & $0 \mathrm{a}$ & $0 \mathrm{a}$ & $0 \mathrm{a}$ & $0 \mathrm{a}$ & $72.2 \mathrm{ab}$ & 4.32 \\
\hline Clopyralid & 200; 200 & $0 \mathrm{a}$ & $0 \mathrm{a}$ & $0.4 \mathrm{abc}$ & $0 \mathrm{a}$ & $71.6 \mathrm{abc}$ & 4.24 \\
\hline Bromoxynil/MCPA & 560 & $0 \mathrm{a}$ & $0 \mathrm{a}$ & $0 \mathrm{a}$ & $0 \mathrm{a}$ & $71.4 \mathrm{abc}$ & 4.22 \\
\hline Bromoxynil/MCPA & $560 ; 560$ & $0 \mathrm{a}$ & $0 \mathrm{a}$ & $0 \mathrm{a}$ & $0 \mathrm{a}$ & 70.7 c & 4.09 \\
\hline Pyrasulfotole/bromoxynil $^{\mathrm{b}}$ & 213 & $0 \mathrm{a}$ & $1.3 \mathrm{~b}$ & $0.2 \mathrm{ab}$ & $2.1 \mathrm{~b}$ & 70.8 bc & 4.15 \\
\hline Pyrasulfotole/bromoxynil $^{\mathrm{c}}$ & $213 ; 213$ & $0.4 \mathrm{a}$ & $3.5 \mathrm{c}$ & $0.2 \mathrm{ab}$ & $3.1 \mathrm{~b}$ & 68.4 def & 3.98 \\
\hline Thifensulfuron/tribenuron + MCPA amine ${ }^{\mathrm{d}}$ & $15+550$ & $0 \mathrm{a}$ & $0 \mathrm{a}$ & $0.4 \mathrm{abc}$ & $0 \mathrm{a}$ & $71.1 \mathrm{abc}$ & 4.21 \\
\hline Thifensulfuron/tribenuron + MCPA amine ${ }^{e}$ & $\begin{array}{l}15+550 \\
15+550\end{array}$ & $2.1 \mathrm{bc}$ & $0.2 \mathrm{ab}$ & $2.7 \mathrm{def}$ & $0 \mathrm{a}$ & $71.3 \mathrm{abc}$ & 4.22 \\
\hline Fluroxypyr + MCPA ester & $108+562$ & $0 \mathrm{a}$ & $0 \mathrm{a}$ & $0.2 \mathrm{ab}$ & $0 \mathrm{a}$ & $72.0 \mathrm{abc}$ & 4.25 \\
\hline Fluroxypyr + MCPA ester & $\begin{array}{l}108+562 \\
108+562\end{array}$ & $0.4 \mathrm{a}$ & $0 \mathrm{a}$ & $0.6 \mathrm{abc}$ & $0 \mathrm{a}$ & $71.2 \mathrm{abc}$ & 4.26 \\
\hline Tralkoxydim $^{\mathrm{f}}$ & 200 & $0 \mathrm{a}$ & $0 \mathrm{a}$ & $0.3 \mathrm{abc}$ & $0 \mathrm{a}$ & $72.4 \mathrm{a}$ & 4.19 \\
\hline Tralkoxydim ${ }^{\mathrm{g}}$ & 200; 200 & $1.0 \mathrm{ab}$ & $0.3 \mathrm{ab}$ & $0.3 \mathrm{abc}$ & $0.5 \mathrm{a}$ & $72.2 \mathrm{abc}$ & 4.31 \\
\hline Fenoxaprop-p-ethyl/safener & 92.4 & $3.2 \mathrm{~cd}$ & $3.4 \mathrm{c}$ & 1.9 cde & $3.0 \mathrm{~b}$ & $69.1 \mathrm{~d}$ & 4.14 \\
\hline Fenoxaprop-p-ethyl/safener & 92.4; 92.4 & $3.9 \mathrm{~d}$ & $5.5 \mathrm{c}$ & $4.7 \mathrm{f}$ & $4.9 \mathrm{c}$ & $66.9 \mathrm{f}$ & 3.96 \\
\hline SE & & 0.1 & 0.2 & 0.2 & 0.2 & 0.3 & 0.05 \\
\hline
\end{tabular}

${ }^{\mathrm{a}}$ Data are averaged for 2008, 2009, 2010. ${ }^{\mathrm{b}}$ Included ammonium sulfate $\left(1.0 \mathrm{~L} \cdot \mathrm{ha}^{-1}\right) .{ }^{\mathrm{C}}$ Included ammonium sulfate $\left(1.0 \mathrm{~L} \cdot \mathrm{ha}{ }^{-1} ; 1.0 \mathrm{~L} \cdot \mathrm{ha}{ }^{-1}\right) .{ }^{\mathrm{d}}$ Included non-ionic surfactant $(0.2 \% \mathrm{v} / \mathrm{v})$. ${ }^{\mathrm{e}}$ Included non-ionic surfactant $(0.2 \% \mathrm{v} / \mathrm{v} ; 0.2 \% \mathrm{v} / \mathrm{v})$. ${ }^{\mathrm{f}}$ Included mineral oil/surfactant $(0.5 \% \mathrm{v} / \mathrm{v})$. ${ }^{\mathrm{g}}$ Included mineral oil/surfactant $(0.5 \%$ $\mathrm{v} / \mathrm{v} ; 0.5 \% \mathrm{v} / \mathrm{v})$.

with pyrasulfotole/bromoxynil increased with time. There was no visible injury at 1 and 2 WAT with pyrasulfotole/bromoxynil however visible injury was as much as $3.5 \%$ at 3 WAT and $3.1 \%$ at 4 WAT in durum wheat. In other studies, Swan [13] found injury in winter wheat when 2,4-D was applied prior to tillering. Sikkema et al. [8] found as much as 7\% injury with dicamba plus MCPA plus mecoprop and minimal injury with 2,4-D amine, dichlorprop plus 2,4-D and bromoxynil plus MCPA in winter wheat. Schroeder and Banks [7] also found that earlier applications of treatments containing dicamba and dicamba plus 2,4-D, contributed to wheat injury in conventional wheat. Wicks et al. [14] and Bailey et al. [15] reported no wheat injury with thifensulfuron-methyl plus tribenuron-methyl ap- plied POST at $47 \mathrm{~g} \cdot \mathrm{ha}^{-1}$ in Virginia, USA. Hageman and Behrens [3] found as much as $11 \%$ injury with chlorsulfuron another sulfonylurea herbicide in durum wheat at Minnesota, USA.

\subsection{Height}

Dichlorprop/2,4-D, clopyralid, bromoxynil/MCPA, thifensulfuron/tribenuron + MCPA amine, fluroxypyr + MCPA ester and tralkoxydim applied POST at the manufacturers' recommended dose and twice that dose caused no adverse effect on height of spring planted durum wheat (Table 2). However, durum wheat height was decreased as much as 5\% with dicamba/MCPA/mecoprop, $4 \%$ with pyrasulfotole/bromoxynil and $6 \%$ with 
fenoxaprop-p-ethyl/safener. In other studies, Xie et al. [4] found no adverse effect on height of durum wheat with fenoxaprop-p-ethyl/safener applied POST at $90 \mathrm{~g} \cdot \mathrm{ai} \cdot \mathrm{ha}^{-1}$. Sikkema et al. [8] found no adverse effect on plant height with 2,4-D amine, bromoxynil plus MCPA, or dichlorprop plus 2,4-D, however dicamba plus MCPA plus mecoprop reduced height as much as $7 \%$ at 600 $\mathrm{g} \cdot \mathrm{ha}^{-1}$ and $11 \%$ at $1200 \mathrm{~g} \cdot \mathrm{ha}^{-1}$ in winter wheat. Martin et al. [16] reported that dicamba plus 2,4-D amine and dicamba plus MCPA reduced wheat height $11 \%$ and $10 \%$, respectively. In other studies, plant height reductions of $16 \%$ were seen in conventional wheat with POST herbicides such as dicamba, dicamba plus MCPA plus mecoprop, dicamba plus 2,4-D amine, dicamba plus MCPA, saflufenacil and mesotrione [8,16-20].

\subsection{Yield}

There was no adverse effect on the yield of durum wheat with the post-emergence application of dichlorprop/2,4-D, dicamba/MCPA/mecoprop, clopyralid, bromoxynil/MCPA, pyrasulfotole/bromoxynil, thifensulfuron/tribenuron + MCPA amine, fluroxypyr + MCPA ester, tralkoxydim and fenoxaprop-p-ethyl/safener at the manufacturers' recommended dose or twice that dose (Table 2). This is similar to the yield response of winter wheat with herbicides such as 2,4-D amine, bromoxynil plus MCPA and dichlorprop plus 2,4-D [8,18,20]. However, in other studies wheat yields were reduced as much as $39 \%$ with dicamba applied POST alone, or in combination with a phenoxy herbicide [6,16,21,22]. Derksen [23] reported significant reduction in wheat yield with MCPA and 2,4-D applied at $2 \mathrm{X}$ doses in the autumn. Tottman [24] also found that tank-mixes containing dicamba, 2,3,6-TBA, MCPA or mecoprop applied POST to winter wheat can reduce grain yield. In another study, saflufenacil applied POST reduced yield of spring wheat 13\% [18]. Mesotrione applied POST caused a decrease in the yield of spring wheat of up to $14 \%$ [20]. Hageman and Behrens [3] found as much as 30\% yield reduction with chlorsulfuron in durum wheat under some environments at Minnesota, USA.

\section{CONCLUSIONS}

Based on this study dichlorprop/2,4-D, clopyralid, bromoxynil/MCPA, thifensulfuron/tribenuron + MCPA amine, fluroxypyr + MCPA ester and tralkoxydim applied POST at the manufacturers' recommended dose can be safely used in durum wheat. However, dicamba/ MCPA/mecoprop, pyrasulfotole/bromoxynil and fenoxaprop-p-ethyl/safener have potential to cause injury especially at twice the manufacturers' recommended dose in durum wheat. Care must be taken to avoid spray over- laps as significant crop injury can occur with twice the manufacturers' recommended dose in durum wheat with these herbicides.

\section{ACKNOWLEDGEMENTS}

The authors acknowledge Todd Cowan for his expertise and technical assistance in these studies. Funding for this project was provided in part by Grain Farmers of Ontario (GFO) and CanAdvance.

\section{REFERENCES}

[1] Canada Food Inspection Agency [CFIA] (2006) The biology of Triticum turgidum ssp. Durum (Durum wheat). Ottawa, 16.

[2] International Grains Council (2002) World grains statistics. 13-17.

[3] Hageman L.H. and Behrens, R. (1981) Response of small-grain cultivars to chlorsulfuron. Weed Science, 29, 414-420.

[4] Xie, H.S., Quick, W.A. and Hsiao, A.I. (1994) Spring cereal response to imazamethabenz and fenoxaprop-pethyl as influenced by environment. Weed Technology, 8, 713-716.

[5] Lemerle, D., Hinkley, R.B., Kidd, C.R. and Leys, A.R. (1986) Symptoms of injury caused by herbicides in wheat and barley. Advisory Bulletin, Department of Agriculture, New South Wales, 4, 1-14.

[6] Rinella, M.J., Kells, J.J. and Ward, R.W. (2001) Response of "Wakefield" winter wheat (Triticum aestivum) to dicamba. Weed Technology, 15, 523-529. doi:10.1614/0890-037X(2001)015[0523:ROWWWT]2.0. $\mathrm{CO} ; 2$

[7] Schroeder, J. and Banks, P.A. (1989) Soft red winter wheat (Triticum aestivum) response to dicamba and dicamba plus 2, 4-D. Weed Technology, 3, 67-71.

[8] Sikkema, P.H., Brown, L., Shropshire, C. and Soltani, N. (2007) Responses of three types of winter wheat (Triticum aestivum L.) to spring-applied post-emergence herbicides. Crop Protection, 26, 715-720. doi:10.1016/j.cropro.2006.06.010

[9] Tottman, D.R. (1980) Varietal differences in the tolerance of cereals to herbicides. Winter Wheat, Crop Conference, 68.

[10] Ontario Ministry of Agriculture, Food, and Rural Affairs [OMAFRA] (2010) Guide to weed control. Publication 75, Toronto.

[11] Senseman, S.A. (2007) Herbicide handbook. 9th Edition, Weed Science Society of America, Champaign, 458.

[12] Statistical Analysis Systems [SAS] (2008) The SAS System for Windows, Release 9.2. Statistical Analysis Systems Institute, Cary.

[13] Swan, D.G. (1975) Necessity for proper timing of application of 2,4-D on winter wheat. Down to Earth, 31, 23-25.

[14] Wicks, G.A., Klein, R.N., Martin, A.R., Lyon, D.J. (1999) Annual broadleaf weed control in winter wheat. $\mathrm{Ne}$ braska Cooperative Extension Report G95-1241-A, Nebraska.

[15] Bailey, W.A, Wilson H.P, Brann D.E. and Griffey, C.A. 
(2004) Wheat cultivar tolerance to AE F13006003. Weed Technology, 18, 881-886. doi:10.1614/WT-03-010R

[16] Martin, D.A., Miller, S.D. and Alley, H.P. (1989) Winter wheat (Triticum aestivum) response to herbicides applied at three growth stages. Weed Technology, 3, 90-94.

[17] Quimby, P.C.Jr. and Nalewaja, J.D. (1966) Effect of dicamba on wheat and wild buckwheat at various stages of development. Weeds, 14, 229-232. doi:10.2307/4040919

[18] Sikkema, P.H., Shropshire, C. and Soltani, N. (2008) Tolerance of spring barley (Hordeum vulgare), oats (Avena sativa) and wheat (Triticum aestivum) to saflufenacil. Crop Protection, 27, 1495-1497. doi:10.1016/j.cropro.2008.07.009

[19] Soltani, N., Shropshire, C. and Sikkema, P.H. (2006) Responses of winter wheat (Triticum aestivum L.) to autumn applied post-emergence herbicides. Crop Protection, 25, 346-349. doi:10.1016/j.cropro.2005.05.012

[20] Soltani, N., Shropshire, C. and Sikkema, P.H. (2011) Responses of spring barley (Hordeum vulgare), oats (Avena sativa) and wheat (Triticum aestivum L.) to meso- trione. Crop Protection, 30, 849-853. doi:10.1016/j.cropro.2011.03.023

[21] Ivany, J.A., Nass, H.G. and Sanderson, J.B. (1990) Effect of time of application of herbicides on yield of three winter wheat cultivars. Canadian Journal of Plant Science, 70, 605-609. doi:10.4141/cjps90-076

[22] Tottman, D.R. (1982) The effects of broad-leaved weed herbicides applied to cereal crops at different growth stages. Aspects of Applied Biology I: Broad-Leaved Weeds and Their Control in Cereals, University of Warwick, Warwick, 201-210.

[23] Derksen, D.A., Kirkland, K.J., McLennan, B.R., Hunter, J.H., Loeppky, H.A. and Bowren. K.E. (1989) Influence of fall and spring herbicide application on winter wheat (Triticum aestivum L. "Norstar"). Canadian Journal of Plant Science, 69, 881-888. doi:10.4141/cjps89-102

[24] Tottman, D.R. (1978). The effects of a dicamba herbicide mixture on the grain yield components of winter wheat Weed Research, 18, 335-339. doi:10.1111/j.1365-3180.1978.tb01170.x 